\title{
The Effects of Movies on the Affective Filter and English Acquisition of Low-Achieving English Learners
}

\author{
Pavithran Ravinthra Nath, Maslawati Mohamad, Hamidah Yamat \\ Faculty of Education, Universiti Kebangsaan Malaysia (UKM), Kajang, Malaysia \\ Email:pavified@yahoo.com
}

How to cite this paper: Nath, P. R., Mohamad, M., \& Yamat, H. (2017). The Effects of Movies on the Affective Filter and English Acquisition of Low-Achieving English Learners. Creative Education, 8, 1357-1378. https://doi.org/10.4236/ce.2017.88096

Received: June 22, 2017

Accepted: July 23, 2017

Published: July 26, 2017

Copyright ( $\odot 2017$ by authors and Scientific Research Publishing Inc. This work is licensed under the Creative Commons Attribution International License (CC BY 4.0).

http://creativecommons.org/licenses/by/4.0/ (c) (7) Open Access

\begin{abstract}
This paper reports on the effects of movies on the acquisition of English language among students at a tertiary institution in Malaysia. In this study, "out-of-class" activities are leisure activities that students do outside classroom setting and watching movie is one example. The study aims to examine the effects of movies on the students' Affective Filter (i.e. motivation, anxiety, and self-confidence). The Affective Filter is a mental block that prevents language learners from being receptive towards comprehensible language input, thereby disrupting their acquisition process. In order for smoother acquisition to occur, the block needs to be lowered and one of the ways in achieving this is through out-of-class activities. The study also aims to examine the influence of movies on the students' English acquisition process. The participants of this study were low-achieving students. Data were collected through Facebook group discussions, participants' reflective notes and focus group interviews in this qualitative research. The findings of this study reveal that students' Affective Filter level is slightly lowered which allowed them to acquire new language skills namely vocabulary and pronunciation knowledge. From the findings, English teachers should consider utilizing movies as a learning tool. Students should consider searching for opportunities to learn outside classroom.
\end{abstract}

\section{Keywords}

Acquisition, Anxiety, Motivation, Movies, Out-of-Class, Self-Confidence

\section{Introduction}

This paper reports on the effects of movies on the acquisition of English language among students in a tertiary institution in Malaysia. English classroom in Malaysian context is often confined to rote-memorization and exam-oriented 
approaches which often resulted in low literacy attainment among the learners (Normazidah et al., 2012). Even though English is formally taught to Malaysian students for a minimum of 11 years, it has been discovered that English proficiency among tertiary students is still underwhelming (Kaur, 2013; Hiew, 2012). It has been suggested that English learning should shift from its current focus on specific language skills learning to a more inclusive, learning-by-doing experience to encourage a meaningful learning (Normazidah et al., 2012). One strategy of doing this is through out-of-class activities. In this study, "out-of-class activities" refer to activities done by learners autonomously in their free time. The activities have been viewed as having significant effects in facilitating the process of English language acquisition among English learners (Chusanachoti, 2009; Sundqvist, 2009; Hyland, 2004). Out-of-class activities consist of daily activities, for examples watching movies and television shows, listening to music and singing, reading and writing for leisure, as well as playing games and using the internet, could provide opportunities for learners to acquire language skills. This approach provides learners the opportunity to implicitly learn the target language while doing activities they love. While there are many activities that can be classified as out-of-class activities, one of the most common and accessible activity is watching movies.

Within Malaysian context, it has been reported that English proficiency among tertiary students in Malaysia is rather unsatisfactory (Hiew, 2012; Kaur, 2013; Nor Hashimah et al., 2008) even though English is taught in primary and secondary level education. In relation to Krashen's hypothesis, it can be postulated that the Affective Filter levels of these learners are high and therefore, their ability to learn the language is disrupted. It can be hypothesized that out-of-class activities can lower these variables because of its association with autonomy (Hyland, 2004), interest (Poupore, 2014) and relaxation (Lin, 2008).

Thus far, many studies of using English movies as language learning tools have been done in other settings, for example in Saudi Arabia (Kabooha, 2016), Japan (Inage et al., 2013) and Macedonia (Ismaili, 2013). Meanwhile in Malaysia, several studies conducted in various universities revealed that movies, among other out-of-class activities, can aid English acquisition process (Hussein \& $\mathrm{Pa}$ rilah, 2014; Melor et al., 2013; Asgari \& Ghazali, 2011). This influences current study to look into this issue within the context of the selected institution because of the limited study conducted in the local setting. By addressing this gap, the study can shed light in whether the findings from previous studies are relevant in the context of the institution and its target participants particularly low achievers. Low achievers are students who struggle academically or perform below the average proficiency level (Carman, 2015: p. 2). They are learners who have not met satisfactory results in the subjects that they are learning.

Two research questions that guide this study are:

1) How do movies affect students' Affective Filter level in learning English as a second language?

2) How do movies affect students' acquisition of English as a second lan- 
guage?

This study attempts to address these questions through Krashen's Second Language Acquisition Theory. Krashen's theory proposed five hypotheses-the Acquisition-Learning Distinction, Natural Order Hypothesis, Monitor Hypothesis, Input Hypothesis and Affective Filter Hypothesis. This study focuses only on Affective Filter Hypothesis which explains that language acquisition process is influenced by variables such as learners' motivation, self-confidence and anxiety (Krahsen, 1982: p. 31). Therefore, it can be assumed that low-achieving learners are negatively affected by the variables. The participants in this study were low-achievers, and they were enrolled in the target institution when this study was conducted. Through case study research design, the effects of movies on their Affective Filter level and English acquisition were studied.

\section{Literature Review}

\subsection{Krashen's Theory of Second Language Acquisition}

Within the context of language acquisition, a "second" language is the language acquired after the mother tongue. Smith (1994) defined second language as a term for any languages a learner acquired other than his first language regardless of how the language is acquired. Ellis (2015) described "acquisition" as the process of picking up a language incidentally and without conscious effort. It occurs naturally without formal instruction and it can be applied to both the first and the second language.

The focus on comprehensible input is also the main idea behind Stephen Krashen's five hypotheses of Second Language Acquisition. These hypotheses, which include the Acquisition-Learning Distinction, Natural Order Hypothesis, Monitor Hypothesis, Input Hypothesis and Affective Filter Hypothesis, suggest that L2 acquisition is input driven and learner's output plays no role in L2 acquisition. The model also emphasized that L2 acquisition is a subconscious process and the features of $\mathrm{L} 2$ the learners acquire are simply the result of them being exposed to it (Krashen, 1982).

Acquisition-Learning Distinction is the first layer of Krashen's SLA theory. In this theory, he explained that language acquisition and language learning should be distinguished from one another because the process in which they occur differs. Acquisition is a subconscious process which occurs without the acquirer's awareness or conscious effort to learn the language-they simply "pick up" the language features because they are exposed towards said language (Krashen, 1982). Meanwhile, language learning is a conscious process of "knowing about" the language - that is to make conscious effort to learn the features of the language (Krashen, 1985).

Natural Order Hypothesis explained that the acquisition of grammatical structures among L2 learners has been observed to follow a predictable order (Krashen, 1982). This hypothesis explained that L2 language features are acquired in similar order regardless of the learners L1. For example, the progress marker-ing and plural marker /s/ are among the first features that learners acquire. 
The emphasis on the subconscious acquisition translates into the Monitor Hypothesis. Krashen (1985) suggested that learners' ability to use L2 comes from acquisition, not learning. The production and the fluency of utterances in L2 is the result of the subconscious knowledge of the L2 (Krashen, 1982, 1985). The role of conscious knowledge is only to "monitor" the production of the language (Krashen, 1982). It acts as an "editor" when L2 is produced through writing or speaking (output) by scanning these outputs and make corrections.

Following the understanding of acquisition and learning, the natural order of language acquisition and the role of conscious knowledge as the monitor, Krashen furthered his theory with the Input Hypothesis. This hypothesis postulated that language acquisition occurs when the meaning, not the form, is understood (Krashen, 1982). When sufficient input within the new language rule is understood, the necessary grammar will be automatically provided. This new language rule is acquired when learners understand the features that is "a little beyond" what they already acquire, above the level they are on in regards to the Natural Order Hypothesis.

The final hypothesis, the Affective Filter Hypothesis, initially proposed by Dulay and Burt (1977), explains that the Affective Filter is a block that prevents comprehensible language input from reaching the mental Language Acquisition Device, thus preventing language acquisition. Krashen (1982) has identified three main variables that influence the Affective Filter-motivation, self-confidence, and anxiety. Motivation can be defined as students' desire to learn a language while experiencing satisfaction in the process (Gardner, 1985). It can be divided into integrative or intrinsic motivation whereby the learner's motivation to learn is driven by their desire to interact with or become closer to the second language community, meanwhile instrumental or extrinsic motivation refers to motivation driven by utilitarian or practical purposes (Gardner \& Lambert, 1959). Meanwhile, self-confidence is defined a psychological and social selfevaluation of one's own competence and worthiness (Rubio, 2007). The final variable, anxiety is defined as the feeling of tension, apprehension, nervousness and worry (Horwitz et al., 1986). Anxiety can be divided into three types, communication apprehension which is the fear of using the second language for communication purposes, test anxiety which is the fear of failing language test, and fear of negative evaluation which is the fear of being evaluated by others, whether this evaluation is real or imagined (Horwitz et al., 1986). Low motivation, low self-esteem and high anxiety could raise the students' affective filter which disrupts acquisition. This study focuses on this hypothesis.

\subsection{Review of Past Studies on Affective Filter Hypothesis}

Mohammadpur and Ghafournia (2015) studied on one of the Affective Filter variables, anxiety. They investigated foreign language reading comprehension achievement of Iranian EFL learners. Data consisted of reading comprehension test and reading anxiety questionnaire was gathered from 100 undergraduate students of varying English proficiency in Islamic University of Neyshabur. The 
researchers found that there is a negative relationship between the participants' reading proficiency and reading anxiety. More stressful learners scored lower in their reading tests compared to less stressful learners. It is suggested that the anxiety hampered the learners' performance because they are distracted by fear of negative evaluation and self-worries. The findings of this study concur with Stevick's (1976) opinion that learners are on the "defensive" in language class.

Dover (2012) conducted a research to determine if there is negative influence of Affective Filter Hypothesis in advanced English students at Universidad Nacional, Nicoya campus in Costa Rica. The participants in this study were eight students of English major. The students displayed reactions related to the Affective Filter like fear and nervousness in oral production. Most of the participants also revealed that their motivation had increased if they are familiar with the topic. In regards to self-confidence, the participants appeared to be uncomfortable talking in front of the class but performed better in smaller groups or with their close friends.

In a study conducted by Lin (2008), Krashen's Affective Filter Hypothesis was tested out in terms of its practical instructional applicability. Ninety-eight intermediate level English learners in MingDao University, Taiwan were selected for the study. After being exposed through classroom activities consisting of games, songs, films and music for 18 weeks, participants' feedbacks showed that learners were positive towards the class activities with majority of the participants claiming that it was relaxing. Moreover, students' grades after training showed significant improvement. Lin (2008) also suggested that similar pedagogical strategies should be adopted in English classes at tertiary level Taiwan which were usually considered as "boring and stressful". However, this study did not address low-performing English learners who might be confused by the lack of instructions in the classroom.

There are also studies carried out to investigate motivation, anxiety and self-confidence independently. A study that aimed to investigate the influence of content-related conditions on task motivation during interactive task, and to identify the interestingness conditions within task content was conducted among 38 adult Korean English learners (Poupore, 2014). In order to achieve these objectives, the participants were asked to complete the task motivation questionnaire and topic preference questionnaire, as well as undergoing interview sessions. The study reveals that tasks with life themes or issues are intrinsically motivating based on the high interestingness level reported by the participants. Moreover, movie or story-based content are also considered interesting because they mostly contain life themes.

A study on motivation was also conducted among primary rural school English learners in Malaysia that aim to identify the students' motivation and attitude towards learning English, as well as their efforts in learning the language (Siti \& Melor, 2014). The findings reveal that the students generally have positive attitudes towards English and they are more extrinsically motivated. It is also discovered that students put more effort in learning in the classroom but did not 
put much efforts in learning outside of classroom, which draws the conclusion that high motivation without minimal effort does not facilitate language acquisition. In terms of the problems they faced, it is discovered that anxiety affects their attitude and motivation.

The study of second language learning anxiety has been conducted among English major students in King Khalid University that aimed to identify the level and sources of English language learning anxiety. The study reported that the students have moderate anxiety, which could enhance motivation (Al-Khasawneh, 2016). In terms of the variance in language anxiety due to study level, it is revealed that there is no positive relationship between the learners' anxiety and their proficiency, and that senior students are more anxious than the freshmen.

Meanwhile, a study of poor English language performance among studentteachers in National University of Laos reveals that the cause of the poor performance is attributed to four factors (Souriyavongsa et al., 2013). While three of the factors concern the lack of well-trained teachers, students' lack of English background knowledge and students' limited opportunity to use English with native English speakers, the third factor is related to the Affective Filter variable of self-confidence, in which it is mentioned that the lack of self-confidence caused the students to become shy and afraid of making mistakes.

Current studies in various contexts had drawn the interest of the researchers to employ such strategies in our own local tertiary institution and embark our own research because it is hoped that our weak students' motivation, anxiety and self-confidence could improved when they are learning through activities that they also do during their leisure time. Even though these studies are conducted in classroom setting, Sundqvist (2009) and Hyland (2004) suggested that bringing these activities outside of classroom can also be beneficial for students' language learning process.

\subsection{The Effects of English Movies towards Language Learning Process}

English movies are easily accessible to language learners and this activity in fact is one of the most common activity the learners do during their free time (Grover et al., 2014; Suh et al., 1999). The idea that leisure activities can be used as language learning tools can be attributed to the fact that the stress-free, autonomous environment is conducive for informal learning and that implicit learning is involved.

Out-of-class learning is informal learning. Benson (2001) defined out-of-class learning as learning activities that occur outside the classroom which are self-instructed, naturalistic and self-directed. Chusanachoti (2009) elaborated that out-of-class English activities or outside of classroom English activities as non-assignment activities carried out in English outside of formal classroom setting, academic or non-academic related done with or without intention to learn English.

Studies on out-of-class activities produced several recurring activities that 
learners do in order to improve their language skill. One of the most common is the use of internet, particularly Web 2.0 applications (Chan, 2016; Che Wan et al., 2014), video call (Correa, 2014) as well as smartphones (Ncube \& Suleman, 2014; Kurtz, 2012). Apart from the internet, the use of gaming as a language learning tool has also been observed in several studies (Bytheway, 2015; Piirainen-Marsh \& Tainio, 2009; Miller \& Hegelheimer, 2006). Other out of class activities that language learners found useful in improving their language skills are through conversation (Jones et al., 2008) and leisure reading (Habibi et al., 2015; Cheng et al., 2009). All in all, out-of-class activities are activities carried out outside the classroom autonomously by the learners without explicit intention to learn the language like pastime activities. Despite the numerous choices of out-of-class activities, current study focuses only on watching English movies.

Ellis (1994) defined implicit learning as "acquisition of knowledge about the underlying structure of a complex stimulus environment by a process which takes place naturally, simply and without conscious operation" (p. 1). Activities like watching movies provide opportunity for implicit learning to occur. Learners are attracted to activities that involve entertainment and watching movie is one of such activity (Hyland, 2004).

It has been observed in several studies that movies can improve learners' language skills and other aspects of language acquisition. A study in Japan involving undergraduate students from five universities were conducted in order to test the strategy of English learning through an English movie and Reader's Theatre assignments (Inage et al., 2013). The study reveals that the students' enjoyment of the movie increased their motivation to learn the language. The participants of the study also reported that this activity had helped improve their pronunciation and vocabulary. However, the study did not provide data on whether the students' English proficiency had increased or not.

A study conducted to examine students' English learning difficulties and the ways they solved these difficulties also reveals the role of watching movies as a learning tool (Nooreiny \& Indira Malani, 2015). The study, conducted in Universiti Kebangsaan Malaysia involving 30 undergraduate students majoring in English Language Studies shows that one method the students use to overcome their learning difficulties is through out-of-class activities including watching western movies. Positive attitudes and high motivation that comes with doing these activities were attributed as the helping factors.

A study conducted among Malaysian secondary school teachers was carried out in order to identify the advantages and disadvantages of using ICT in teaching reading and writing (Melor et al., 2013). By interviewing English teachers in several Malaysian schools, it is discovered that students watching movies with subtitles could increase their vocabulary knowledge.

The roles of motivations and attitudes are also explored by Hussein and Parilah (2014) in a study conducted in the same university involving 30 undergraduate students. It is discovered that a majority of the students have positive attitudes regarding watching English movies for learning English. It is explained 
that the students developed positive attitudes because of their interest in the American culture and therefore are motivated to learn the language for integrative purpose.

Meanwhile, a case study conducted among four English Education students in Thailand to explore their engagement in English activities outside of classroom has revealed that engagement in English movies is beneficial for vocabulary acquisition as well as the learning of colloquial expression and slang-the conversational aspect of English that is not usually taught in a formal classroom setting (Chusanachoti, 2009). Moreover, movies also helped learners to contextualize words because characters in movies talk about various topics in various context. This study also revealed that movies contribute to the learning of pronunciation and different English accents.

Based on these studies, it could be observed that the studies on the use of movies as a language learning tool, whether it is for in-class activities or out-of-class activities, exist. Generally, movies are able to facilitate language acquisition which supports Krashen's view-exposure to the language can help in the subconscious acquisition of the language meaning. In Malaysian context, watching English movies is a reoccurring motive in the study of out-of-class activities. While these previous studies look at out-of-class learning in a wide scope, current study narrows it to English movies only. In addition, this study also attempts to address the lack of research conducted in current research site, which is a private tertiary institution in Malaysia.

\section{Methodology}

\subsection{Research Design}

This study employs qualitative research approach. Merriam (2009) mentioned that qualitative research is employed in order to understand human's interpretation of their experiences (p. 12). Therefore, in the effort of understanding low-achieving English learners experience in learning through movies, qualitative research is deemed appropriate. This is because autonomous learning is context-specific and student-centered, which can therefore be difficult to study through quantitative data especially in the context of out-of-class learning whereby the activity is conducted within the participants' personal space (Chan, 2012). Therefore, qualitative approach is more suitable because it offers deeper insight into the participants' experience.

More specifically, case study research design is chosen. Merriam (2009) described case study as "the search for meaning and understanding, the researcher as the primary instrument of data collection and analysis, an inductive investigative strategy, and the end product being richly descriptive" (p. 39). This study seeks to understand the phenomenon of out-of-class activities through thick and descriptive insights provided by the participants over a certain period.

\subsection{Research Setting and Participants}

The research setting of this study is a Malaysian private tertiary education insti- 
tution. This institution has six campuses across Malaysia with its main campus situated in Kuala Lumpur. This study is undertaken only in one campus branch. This branch offers several diploma programs like science, business studies, entrepreneurship, hotel management, aquaculture and mass communication.

English is widely used in the institution in the academics because the subjects are taught in English. Therefore, English is the primary medium of instruction in the institution whereby the classes are conducted in English and the students' assignments are written in English. This policy has been reported by a study by Azirah and Leitner (2004) which explained that English is the preferred medium of instruction in Malaysian private institutions. Even though English program is not offered, English subjects are offered. Two English subjects-English Language and English for Communication are compulsory subjects, meanwhile English Language (1119 Level) is compulsory for students with SPM English grade $\mathrm{C}$ and below.

In general, the students of this institution display intermediate level of English proficiency. Very few students are of high proficiency even though English is the main medium of instruction. Most of the students are more comfortable in using Mandarin because the majority of them are Chinese.

The selection of participants was carried out based on purposive sampling. Purposive sampling refers to researchers intentionally select participants who fulfill the required criteria (Cresswell, 2014: p. 206). The main criterion for the sampling is that the participants must be low-achieving English learners. Therefore, the selection is based on their English Language examination grade in Sijil Pelajaran Malaysia (SPM), which must be D and lower. SPM result was chosen as the benchmark because it is a standardized examination taken by all Malaysian students at the end of their secondary school. Six second year students, Lee, Rose, Sharon, Sia, Will and Yen (pseudonyms), aged 19 to 21, were selected because they met this criterion. All of them had enrolled in English Language class.

\subsection{Research Ethics}

Ethical considerations are adhered to while carrying out the study in which the students volunteered themselves in this study. Their consent was obtained and pseudonyms were used in this report.

\subsection{Research Instruments}

In order to collect data, Facebook group discussion thread, reflective notes and semi-structured focus group interview responses were utilized. The participants were required to discuss the movies in a Facebook group based on prompts provided by the researchers. Facebook is useful as a method to collect self-report data (Kosinski, et al., 2015: p. 550) and provides community interactions among the participants (Mills, 2011).

The second research instrument is reflective note whereby the participants recorded their thoughts in personal writing. This instrument is a good data source because it is written in the words of the participants themselves (Creswell, 
2014: p. 223) and it can be used to corroborate and augment data from other sources or instruments (Yin, 2009: p. 103). Meanwhile, semi-structured focus group interview responses enable collective brainstorming and collaboration among the participants without constraining their responses (Dörnyei, 2007: p. 144). The main questions prompted on all three instruments touched on:

1) Their opinion about aspects of the movie (this is used to observe their language use);

2) The influence of the movies on their Affective Filter level;

3) Helpfulness of movies in improving their English.

The instruments are abbreviated as (Facebook) for Facebook group discussion, (R.N.) for reflective notes, and (Interview) for semi-structured focus group interview.

\subsection{Data Collection and Analysis}

The data is collected through three research instruments-Facebook group discussion thread, reflective notes and semi-structured focus group interview responses. The movies selected were Moana (2016), an animated film about a young woman's adventure to save her dying island from mystical dark force, and Hacksaw Ridge (2016), a biographical war drama film about a combat medic who refused to carry firearm to war and later awarded for his bravery. Before watching the movies, an initial discussion was conducted whereby the researchers elicited information on the reasons why the participants selected these movies by relating them to their motivation, anxiety and self-confidence.

After the initial discussion, the participants were required to watch Moana. After watching the film, they were asked to discuss the movie in the Facebook group as well as writing a one page personal reflective note based on instructions provided by the researchers. The second film viewed by the participants was Hacksaw Ridge. The duration given was one week for each movie.

Next, they were interviewed. These steps were repeated after the second movie. The participants were allowed to use Malay and English so that they would be able to express themselves without language constrain. Malay is a national language in Malaysia in which all Malaysians are able to speak the language.

The interview session was tape-recorded and later transcribed in verbatim. Thematic analysis was applied on the Facebook discussion threads, reflective notes and interview transcriptions in order to observe emerging themes.

\subsection{Validity and Reliability}

It is acknowledged that the researchers have personal biases considering that they have experience learning and teaching English as a second language, and they have experiential insight that out-of-class activities do affect learners' ability to learn a second language. In order to prevent personal bias from undermining the study and to ensure the reliability of the results, several strategies have been utilized.

Reliability can be defined as the stability and consistency of the research in- 
strument (Cresswell, 2014: p. 177). For this study, one strategy employed to maintain the research reliability is through triangulation. Triangulation is defined as using more than one data sources, methods, investigators, theoretical perspectives and approaches to study one phenomenon (Brink, 1993: p. 37). This study uses Facebook group discussions, participants' reflective notes, and semi-structured focus group interviews to collect data. The data are compared and crosschecked in order to find consistency in the findings. Consistent findings from more than one method will improve the credibility of the study. Peer check is another strategy utilized to ensure the reliability of the research. In this study, peer checking is performed by having the transcriptions of the interviews checked by some of the participants for accuracy.

Validity refers to "the degree to which all of the evidence points to the intended interpretation of test scores for the proposed purpose" (Cresswell, 2014: p. 177). Therefore, validity is the level of accuracy of the instrument in which the instrument is valid for their intended purpose. A strategy used in this study to shore up validity is through respondent validation. Merriam (2009) defined this strategy as soliciting feedbacks regarding the findings from the research participants (p. 246). In this study, respondent validation is carried out by showing the interview transcriptions to the participants for comments and verification in order to improve the accuracy. Moreover, the data gathered from all research instruments are shown to the participants to ensure that the researcher had transcribed and interpreted their opinions and utterances correctly.

\section{Findings}

To reiterate, the research questions are:

1) How do movies affect students' Affective Filter level in learning English as a second language?

2) How do movies affect students' acquisition of English as a second language?

The first research question is addressed in the first subtopic whereby learners' motivation, anxiety and self-confidence level are discussed. The second research question is addressed in the following subtopic in which learners' English acquisition is discussed. The instruments are abbreviated as (Facebook) for Facebook group discussion, (R.N.) for reflective notes, and (Interview) for semi-structured focus group interview.

\subsection{Affective Filter Level}

The following subsection will discuss the answer to research questions 1-How do movies affect students' Affective Filter level in learning English as a second language? Affective Filter variables consist of motivation, anxiety and self-confidence. The findings for each variable are discussed by sections.

\subsubsection{Motivation}

Before watching the movies, a few of the participants reported that they had low motivation in learning English. Lee, Sharon, Sia and Will mentioned that they 
disliked English language classroom environment for being boring, confusing and stressful. They mentioned,

"In class, very bored because lost. Sometimes hard to follow lecturer explanation. So stress. Don't know what to learn. Not interesting". (Lee, Interview)

"Maybe not in class because it's a bit boring". (Sharon, Interview)

"I have interested to learn English but I would not looking forward to English classes because the English classes maybe boring and will spent my a lot of time and money ..." (Sia, Facebook)

"English is awesome but difficult. Because difficult, I sometimes not interested to learn English when I in school”. (Will, R.N.)

Boring and stressful environment can hamper students' motivation (Lin, 2008). Despite not being motivated by classroom environment, they acknowledged the importance of English, displaying characteristics of extrinsic motivation that is not manifested through efforts in learning, a scenario that has also been observed by Siti and Melor (2014). However, some of the participants did express motivation in English learning. Yen claimed that she did not avoid English and in fact, was motivated enough to enroll in English courses. Despite having high motivation, she commented that her English proficiency as low. She mentioned:

"I feel motivate to learn English to improve myself. If possible, I will consider to join some short course for speaking part". (Yen, Facebook)

"For English, I weak in terms of conversation and writing". (Yen, R.N.)

This indicates that other Affective Filter variables, which are anxiety and selfconfidence are interfering with their acquisition process. Krashen (1982) mentioned that the most optimal condition for language acquisition to occur is when these variables are the lowest.

After viewing the movies, the participants reported that their motivation level had increased. The participants mentioned that this strategy is more interesting and therefore motivates them to learn. For example,

"I feel movie is more fun and motivating to learn English than in class". (Yen, R.N.)

Yen explained that she was not able to learn much in the classroom setting because of the boring environment. By learning through out-of-class activities that interest her, she felt more motivated. This statement is echoed by Rose who commented that learning English by watching movies provides more excitement for the learners.

“... it very fun to learn English with watching movie. Because before this, when I study I never learn about English and I think it so boring". (Rose, Interview)

"Actually, we get more fun and interesting to learn with movies ..." (Rose, R.N.) 
The findings support the notion that interesting contents can affect learners' motivation (Poupore, 2014; Inage et al., 2013). It can be observed that movies could have positive impact on the participants' motivation. Krashen's Affective Filter Hypothesis mentioned that motivation as one of the variables in language acquisition process. He mentioned that highly motivated learners can acquire language skills easier (Krashen, 1982). It has been observed that the interestingness of the movies and songs had increased participants' motivation and they became more receptive towards language input.

\subsubsection{Anxiety}

All participants reported that they have high level of anxiety when it comes to using English. They reported that they are scared of being laughed at. They reported,

"If I speak, I am shy of my reasons later people laugh my messy English". (Lee, R.N.)

"I am scared to peoples will laugh at me, it makes me shy. If peoples spoke to me, I will speak to them with malay because I am scared". (Sharon, R.N.)

" $P \mathrm{~m}$ scared that my grammar and vocabulary is wrong and people will laugh at me. Because I have experience before this". (Sia, Interview)

"I want to learn about English but I am afraid and I m shy to use English because my friends will laugh on me when I use the broken English". (Yen, Interview)

This can be considered as the manifestation of fear of negative evaluation (Mohammadpur \& Ghafournia, 2015). According to Al-Khasawneh (2016), fear of negative evaluation occurs when students are not prepared to answer teachers' questions or they do not know what teachers are correcting. However, this type of anxiety can also occur without the presence of teachers. Horwitz et al. (1986) explained that fear of negative evaluation occurs when learners are apprehensive about being evaluated by others and therefore prefer to avoid being in evaluative situations. This is further exemplified by Sharon who mentioned,

“... but I can't speak well, peoples in surrounding will keep on their eyes to see me and makes me not comfortable". (Sharon, R.N.)

"When I speak, I don't like when people keep looking at me-sometimes smile, sometimes laugh a bit, like they wait for me to say wrongly". (Sharon, Interview)

The anxiety caused by the fear of being laughed and stared at when using English is caused by her sense of being evaluated. Other participants reported that they share similar feeling.

The participants also reported that their anxiety has been slightly reduced after watching the movies. With lower anxiety, the participants' perception of English learning improved. Lee and Sharon indicated that they are better prepared to learn and use English more because of their reduced anxiety level.

"Not so scare already because I am trying to learn more". (Lee, Facebook) 
"Now is no, but previous was yes. Because before this P $m$ very shy and communicate with the people in English". (Sharon, Interview)

Meanwhile, Sia explained that he no longer experienced high anxiety when using English in smaller groups.

"Learning new words and pronunciation from the movie is make me feel better to talk in small group and with friends". (Sia, R.N.)

In general, the participants reported that their anxiety level has decreased in varying degrees. Some admitted that they were still anxious but were improving slightly and others claimed to have experienced improvements that are more significant.

"Still scared, but I not as scared as before". (Rose, Facebook)

"Cannot say not scared of people laughing also. But I feel a bit better".

(Will, Facebook)

However, most of them agreed that watching movies as a learning tool is produces less anxiety, a finding that echoes Lin's (2008). Without the sense of being judged, the participants are able to lower their anxiety. In general, the participants reported that movies as a learning tool is more relaxing which is concurrent with the findings of other previous studies (Chan, 2016; Inage et al., 2013; Lin, 2008). Krashen (1982) mentioned that learners with low anxiety are more receptive towards language input.

\subsubsection{Self Confidence}

For self-confidence, the participants reported that they have low self-confidence prior to the study. Their lack of self-confidence in using the language is linked to their poor proficiency in various language skills causing them to become afraid or embarrassed of making mistakes, similar to findings by Souriyavongsa et al. (2013). Most of them claimed that they are least confident in oral communication skill because of their low vocabulary and grammar knowledge, as well as their pronunciation. They mentioned,

"Actually I am not confident in using English because there are so many words that I do not understand. I only can understand if others are using simple English talk to me”. (Lee, Facebook)

"In my opinion, I'm not really confident about my English. I'm feared when I speak that my grammar I vocabulary is wrong and people will laugh at me". (Sia, R.N.)

"P $m$ not confident to use English because my English is very broken English". (Yen, Interview)

The participants' reported that their self-confidence level slightly improved during the course of the study. After viewing the movies, the participants mostly claimed that they were still not very confident. For example, Lee, Sharon and Yen mentioned that while their confidence level had increased slightly, they were still not too confident in their ability. 
"Maybe not yet confident to talk to people ..." (Lee, R.N.)

"Maybe not confident enough yet, but I will try my best to improve myself".

(Sharon, Facebook)

"For me, maybe rise a little bit because need to learn more to really confi-

dent". (Yen, Facebook)

However, a few were willing to apply the words that they had learned from the movies in conversations with friends and in class works.

"Yes, I also confident to use words that I already learn in that movies in my essay at class". (Sia, Facebook)

"I feel confident with the words that I learn in that movie when I talk with my friends at school ..." (Will, Interview)

However, some did not feel the effect of the slight increase in their self-confidence level. For instance, Rose claimed that while her self-confidence had improved, she was still not confident enough to have conversation in English even with her friends.

"I've a little bit improvement, but not too confident to talk or conversation with my friends. Because I did not practice English in daily life". (Rose, Facebook)

Meanwhile, Lee and Sia mentioned that they are getting more confident in using English in smaller groups, a result similarly observed in a study by Dover (2012).

"Maybe in small group like this I more confident ..." (Lee, Interview)

"I can be more confident in small groups like discussion group". (Sia, R.N.)

Generally, the participants had shown the increase in their self-confidence level after engaging in the activity. Initially, their lack of self-confidence in using the language is linked to their poor proficiency in various language skills causing them to become afraid or embarrassed of making mistakes, similar to findings by Souriyavongsa et al. (2013). Krashen (1982) mentioned that learners with high self-confidence and good self-image could acquire second language better.

Krashen explained that language learners who have low level of Affective Filter become more receptive towards language learning. They will seek more language input and the input can reach the part of the brain responsible for language acquisition easier. The participants have reported that their motivation and self-confidence increased, and their anxiety lowered. Therefore, their ability to acquire language had been improved as discussed in the following section.

\subsection{Language Acquisition}

The following subsections will discuss the answer for research question 2-How do movies affect students' acquisition of English as a second language?

When asked on the English components they have learned, vocabulary acquisition is the most popular response among the participants. In the reflective 
notes, they were requested to list down the words that they have learned including the searching of definition of words. For the definition, the participants applied three strategies, which are using dictionary definition, translating the words into Malay and writing the definition using their own words. For example, after viewing the first movie, Lee defined a new word he learned, "shapeshifter" by using dictionary definition. After viewing the second movie, he defined the new word he learned, "court-martial" by translating it into Malay without using translation dictionary.

During the interview session, some participants are able to explain the meaning of the word in English. For example, when prompted on the meaning of the word "ancestors", Sia explained,

“'Ancestors' ... is our grandma, grandma, a mother from grandma ..." (Sia, Interview)

His definition, while unpolished, is able to capture the meaning of the word, attesting to his comprehension of the word. This also shows that he had enough self-confidence to attempt a response in English.

The participants' ability to create new sentences from the words that they have learned also shows that they understand the meaning of the words and the way they appear within context. This supports the findings by Chusanachoti (2009) which reveal that learners can learn word context through movies. Although their responses are not prompt and sometimes ungrammatical, they proved that they are able to place the word within the right context. For example,

"Roam'. That is 'merayau'. Moana like to roam around the ... island". (Sia, Interview)

"And I learn miracle. Means like magic ... It's a miracle he is still alive". (Lee, Interview)

Apart from the vocabulary knowledge, some of the participants also mentioned that they have learned pronunciation. During the interview, Sharon brought out a point,

"And pronunciation also. Hear how real English pronounce words. Sometimes different then how teachers teach me". (Sharon, Interview)

Considering the participants have not experienced face-to-face pronunciation lessons from native English speakers, their pronunciation are mostly modeled after their local teachers and peers. Movies allowed them to listen to the pronunciation of native English speakers and therefore facilitate their pronunciation skills. The improvement of pronunciation skills has been discussed by Inage et al. (2013) and Chusanachoti (2009).

Krashen's theory of Second Language Acquisition foregrounds the role of subconscious acquisition based on the exposure to comprehensible language input. The Affective Filter hypothesis from this theory also explained the role of motivation, anxiety and self-confidence as factors in determining the amount of language input that can be transferred into the language acquisition device. In 
this study, it has been observed that movies provide the opportunity for learners to lower their Affective Filter level and therefore allowed them to acquire certain language skills.

\section{Discussion}

Through the lens of Krashen's Affective Filter Hypothesis, low-achieving English learners can be described as learners with low motivation, high anxiety, or low self-confidence. These variables can be observed among the participants of this study whereby the variables were reported to be related to their low English ability and as their level of affective filter was gradually lowered, they became more receptive towards language learning.

The participants started with varying levels of motivation. Some students reported that they were motivated to learn English and some were not motivated to learn. However, most had unfavorable view towards learning in classroom setting. This finding supports Lin's (2008) study which commented that students are more motivated in a less boring and stressful classroom. It is also discovered that all of the participants, despite their varying degree of motivation realized the importance of English and the need to learn it. However, even with this realization, their proficiency remains low. This shows that motivation without putting effort does not improve one's English ability (Siti \& Melor, 2014). Through watching movies, the participants' motivation level gradually increased. The main factor being that they found the movies interesting. The participants recounted that the activity is more entertaining and interesting than classroom lessons and it kept them motivated. This supports the findings by Nooreiny and Indira Malani (2015), and Hussein and Parilah (2014).

The participants also reported that their anxiety level had gradually decreased. Prior to the study, all participants had high anxiety. They were reluctant to speak and their utterances were disrupted by hesitancy and stutters. Most of them claimed that they are nervous to use English because of the sense of negative evaluation (Al-Khasawneh, 2016; Mohammadpur \& Ghafournia, 2015). The feeling of anxiety hindered them from practicing their English, especially oral skill, a similar issue noted by Dover (2012). The movies provided them with relaxing environment to learn the language at their own pace, as well as a common subject for discussion among the participants. The association to a more relaxing environment while doing such activities for learning has been noted by Lin (2008). They reported that their anxiety gradually diminished throughout the sessions.

In terms of self-confidence, all participants reported that they had low selfconfidence prior to the study. The main reason for their low self-confidence is related to their lack of language skills especially in active and immediate usage like speaking. Their lack of vocabulary and grammar knowledge and poor pronunciation affected their fluency and in turn lower their self-confidence. Movies improved their self-confidence level overall. By learning new words and proper pronunciation of words, the participants reported that their self-confidence level 
had improved. Some participants mentioned that they had become confident in using English in smaller groups or with friends. This is similarly observed in Dover (2012) whereby students performed better in smaller groups or close friends in comparison to speaking with people who they are not comfortable with. Similar to anxiety, some participants reported that their self-confidence level does not improve greatly but still admitted that they feel slightly more confident. The improvement in their self-confidence was observable during the interview session whereby they were more confident in giving their opinions with less pauses and hesitancies.

In comparison to the first and the final session, the participants' English ability had slightly improved. The participants reported that they have learned new words, similarly reported in previous studies (Inage et al., 2013; Melor et al., 2013; Chusanachoti, 2009), and pronunciation, also similar to previous findings (Inage et al., 2013; Chusanachoti, 2009). Many claimed that they will start using these words and the correct pronunciation in their writing and conversation.

\section{Conclusion}

Based on the findings, it could be concluded that movies have positive effects on learners' Affective Filter level. When the Affective Filter level is lowered, their English language acquisition process is facilitated.

\subsection{Summary}

In conclusion, out-of-class activities in particular watching movies could lower students' Affective Filter level due to several factors. Motivation is raised because students are more interested in the content of the materials. Anxiety is lowered because the students are more relaxed while being engaged in this activity. The rise in their self-confidence also helped to ease their anxiety when using and learning the language. Self-confidence itself is gained when the students realized that they have learned new language knowledge and skills that they can use in their daily life. By lowering the Affective Filter variables, the process of language acquisition can occur smoothly. Students, who are motivated and confident, with low anxiety, are more receptive to comprehensible language input which contributes to the acquisition of the language. Watching movies is able to lower the filters and therefore, students' acquisition of English can occur.

\subsection{Implication of the Study}

The researchers studied the effects of movies on English learners' acquisition process in our local institution. While the study of using movies as learning tool is not a new treading ground, this study shows that researches on movies can also be conducted as an out-of-class activity whereby learning could occur without teachers' guidance. Participants were given liberty to watch the movies during their own leisure time under the notion that doing so could have positive effects on their motivation, anxiety and self-confidence, more so than if it is conducted within the classroom setting. This relates to the notion that out-of-class activities 
foster learner autonomy which facilitates the internalization of English learning instead of solely learning for examination purposes (Chan, 2016).

The findings of this study are beneficial to English instructors who are dealing with low-achieving students. By recognizing that movies are viable options to reinforce learning, instructors can attempt to integrate this strategy into their curriculum. The findings can also encourage learners to seek for opportunity to learn and use English outside of the classroom. By realizing that they can create their own opportunities to learn while doing leisure activities of their preference, learners will be encouraged to practice the language outside the classroom which will in turn increase their English language skills.

\subsection{Limitations of the Study}

This study is limited by small samples of the research setting. Moreover, only one out of six branches was studied. Therefore, the result is not reflective of the institution as a whole. Mason (2010) in his analysis of sample size and saturation in $\mathrm{PhD}$ qualitative studies using interviews discovered that the common sample sizes are 20 and 30, which as he claimed followed the guideline provided by Bertaux (as cited in Mason, 2010) who proposed that the minimum sample size for any qualitative study as 15 . Secondly, this study limits its focus on only one out-of-class activities. Out-of-class activities cover a vast spectrum of activities that language learners do at home and the community without the constraint of classroom hour (Hyland, 2004).

\subsection{Suggestions for Future Research}

Therefore, for future researches, bigger sample size involving other branches of the institution should be considered for result that is more representative of the context of the institution. Moreover, considering that the research is interested in looking at the role of out-of-class activities on language acquisition, other types of out-of-class activities can also be included for a better representation of out-of-class activities.

\section{References}

Al-Khasawneh, F. M. (2016). Investigating Foreign Language Learning Anxiety: A Case of Saudi Undergraduate EFL Learners. Journal of Language and Linguistic Studies, 12, 137-148.

Asgari, A., \& Ghazali, M. (2011). The Type of Vocabulary Learning Strategies Used by ESL Students in University Putra Malaysia. English Language Teaching, 4, 84-90.

Benson, P. (2001). Teaching and Researching Autonomy in Language Learning. Harlow: Pearson Education.

Brink, H. I. L. (1993). Validity and Reliability in Qualitative Research. Curationis, 16, 35 38. https://doi.org/10.4102/curationis.v16i2.1396

Bytheway, J. (2015). Digital Learning outside the Classroom. International Education in the Digital Age, 17, 21-22.

Carman, L. K. (2015). Low-Achieving Students' Perspectives Regarding Their Experiences 
as Recipients of Instructional Support Delivered in a General Education Setting. Ph.D. Thesis, Newark, NJ: The State University of New Jersey.

Chan, H. W. (2012). Learner Autonomy, Agency, and Affordances: Multiple Case Studies of the Out-of-class English Learning of Highly Proficient University Students in Hong Kong. Ph.D. Thesis, Ann Arbor, MI: ProQuest.

Chan, H. W. (2016). Popular Culture, English Out-of-Class Activities, and Learner Autonomy among Highly Proficient Secondary Students in Hong Kong. Universal Journal of Educational Research, 4, 1918-1923. http://dx.doi.org/10.13189/ujer.2016.040823

Che Wan, I. R., Chen Wan, I., Prain, V., \& Collet, P. (2014). Perceived Learning Strategies of Malaysian University Students in Web 2.0-Based English as a Second Language Informal Learning. GEMA Online ${ }^{\circledast}$ Journal of Language Studies, 14, 29-42. http://dx.doi.org/10.17576/GEMA-2014-1401-03

Cheng, L., Klinger, D. A., \& Zheng, Y. (2009). Examining Students' After-School Literacy Activities and Their Performance on the Ontario Secondary School Literacy Test. Canadian Journal of Education, 32, 118-148.

Chusanachoti, R. (2009). EFL Learning through Language Activities outside the Classroom: A Case Study of English Education Students in Thailand. Ph.D. Thesis, Ann Arbor, MI: ProQuest.

Correa, Y. R. (2014). Skype ${ }^{\mathrm{Tw}}$ Conference Calls: A Way to Promote Speaking Skills in the Teaching and Learning of English. Profile Issues in Teachers' Professional Development, 17, 143-156. http://dx.doi.org/10.15446/profile.v17n1.41856

Creswell, J. W. (2014). Educational Research: Planning, Conducting and Evaluating Quantitative and Qualitative Research (4th ed.). Harlow: Pearson.

Dörnyei, Z. (2007). Research Methods in Applied Linguistics. Oxford: Oxford University Press.

Dover, Y. (2012). Affective Filter Influence on Students' Initiating the B.A. English Major at the Universidad Nacional, Chorotega Branch in Nicoya, Guanacaste, Costa Rica. Revista Ensayos Pedagógicos, 6, 169-188.

Dulay, H., \& Burt, M. (1977). Remarks on Creativity in Language Acquisition. In M. Burt, H. Dulay, \& M. Finocchiaro (Eds.), Viewpoints on English as a Second Language (pp. 95-126). New York: Regents.

Ellis, N. (1994). Implicit and Explicit Learning of Languages. London: Academic Press.

Ellis, R. (2015). Understanding Second Language Acquisition. Oxford: Oxford University Press.

Gardner, R. C. (1985). Social Psychology and Second Language Learning: The Role of Attitudes and Motivation. London: Edward Arnold. https://doi.org/10.1037/h0083787

Gardner, R. C., \& Lambert, W. E. (1959). Motivational Variables in Second-Language Acquisition. Canadian Journal of Psychology, 13, 266-272.

Grover, K. S., Miller, M. T., Swearingen, B., \& Wood, N. (2014). An Examination of the Self-Directed Learning Practices of ESL Adult Language Learners. Journal of Adult Education, 43, 12-19.

Habibi, H., Awang Had, S., \& Manvender, K. S. S. (2015). The Effect of Reading on Improving the Writing of EFL Students. Pertanika Journal of Social Sciences \& Humanities, 23, 1115-1138.

Hiew, W. (2012). English Language Teaching and Learning Issues in Malaysia: Learners' Perceptions via Facebook Dialogue Journal. Journal of Arts, Science \& Commerce, 3, $11-19$.

Horwitz, E. K., Horwitz, M. B., \& Cope, J. (1986). Foreign Language Classroom Anxiety. 
The Modern Language Journal, 70, 125-132.

https://doi.org/10.1111/j.1540-4781.1986.tb05256.x

Hussein, I. A., \& Parilah, M. S. (2014). Motivation and Attitudes towards Learning English among Undergraduates in National University of Malaysia (UKM). International Journal of English and Education, 3, 209-227.

Hyland, F. (2004). Learning Autonomously: Contextualizing Out-of-Class English Language Learning. Language Awareness, 13, 180-202. https://doi.org/10.1080/09658410408667094

Inage, I., Lawn, E., \& Lawn, M. (2013). An Analysis of Student Motivation in an ESL Classroom by Using a Movie and Reader's Theatre Styled Assignments: Based on Student Feedback. Bulletin of Faculty of Education, Nagasaki University: Curriculum and Teaching, 53, 61-63.

Ismaili, M. (2013). The Effectiveness of Using Movies in the EFL Classroom-A Study Conducted at South East European University. Academic Journal of Interdisciplinary Studies, 2, 121-132. http://dx.doi.org/10.5901/ajis.2012.v2n4p121

Jones, M. H., Estell, D. B., \& Alexander, J. M. (2008). Friends, Classmates, and Self-Regulated Learning: Discussion with Peers inside and Outside the Classroom. Metacognition Learning, 3, 1-15. https://doi.org/10.1007/s11409-007-9007-8

Kabooha, R. H. (2016). Using Movies in EFL Classrooms: A Study Conducted at the English Language Institute (ELI), King Abdul-Aziz University. English Language Teaching, 9, 248-257. https://doi.org/10.5539/elt.v9n3p248

Kaur, N. (2013). A Case Study of Tertiary Learners' Capability in Lexical Knowledge. GEMA Online ${ }^{\text {Tw } J o u r n a l ~ o f ~ L a n g u a g e ~ S t u d i e s, ~ 13, ~ 113-126 . ~}$

Kosinski, M., Matz, S. C., Gosling, S. D., Popov, V., \& Stillwell, D. (2015). Facebook as a Research Tool for the Social Sciences: Opportunities, Challenges, Ethical Considerations, and Practical Guidelines. American Psychologist, 70, 543-556. http://dx.doi.org/10.1037/a0039210

Krashen, S. D. (1982). Principles and Practice in Second Language Acquisition. New York: Pergamon.

Krashen, S. D. (1985). The Input Hypothesis: Issues and Implication. New York: Longman.

Kurtz, L. M. (2012). Learning from Twenty-First Century Second Language Learners: A Case Study in Smartphone Use of Language Learners. Master's Thesis, Ames, IA: Iowa State University.

Lin, G. H. C. (2008). Pedagogies Proving Krashen's Theory of Affective Filter. Hwa Kang Journal of English Language \& Literature, 14, 113-131.

Mason, M. (2010). Sample Size and Saturation in PhD Studies Using Qualitative Interviews. Forum Qualitative Sozialforschung/Forum: Qualitative Social Research, 11. http://www.qualitative-research.net/index.php/fqs/article/view/1428/3027

Melor, M. Y., Norazah, N., Hadi, S., Choo, H. S., \& Mohamad, A. E. (2013). Pros and Cons of Using ICT in Teaching ESL Reading and Writing. International Education Studies, 6, 119-130.

Merriam, S. B. (2009). Qualitative Research: A Guide to Design and Implementation. San Francisco, CA: Jossey-Bass.

Miller, M., \& Hegelheimer, V. (2006). The Sims Meet ESL Incorporating Authentic Computer Simulation Games into the Language Classroom. Interactive Technology \& Smart Education, 3, 311-328. http://dx.doi.org/10.1108/17415650680000070

Mills, N. (2011). Situated Learning through Social Networking Communities: The Development of Joint Enterprise, Mutual Engagement, and a Shared Repertoire. CALICO 
Journal, 28, 345-368. https://doi.org/10.11139/cj.28.2.345-368

Mohammadpur, B., \& Ghafournia, N. (2015). An Elaboration on the Effect of Reading Anxiety on Reading Achievement. English Language Teaching, 8, 206-215. https://doi.org/10.5539/elt.v8n7p206

Ncube, S. P., \& Suleman, H. (2014). Complementing Formal Learning with Mobile Technology outside the Classroom. In Institute of Electrical and Electronics Engineers (Ed.), Proceedings of International Conference on Interactive Mobile Communication Technologies and Learning (pp. 51-56). New York: Institute of Electrical and Electronics Engineers.http://dx.doi.org/10.1109/IMCTL.2014.7011103

Nooreiny, M., \& Indira Malani, M. (2015). Learner's Learning Experiences \& Difficulties towards (ESL) among UKM Undergraduates. Advances in Language and Literary Studies, 6, 83-87. http://dx.doi.org/10.7575/aiac.alls.v.6n.3p.83

Nor Hashimah, J., Norsimah, M. A., \& Kesumawati, A. B. (2008). The Mastery of English Language among Lower Secondary School Students in Malaysia: Linguistic Analysis. European Journal of Social Sciences, 7, 106-119.

Normazidah, C. M., Koo, Y. L., \& Hazita, A. (2012). Exploring English Language Learning and Teaching in Malaysia. GEMA Online ${ }^{\tau m}$ Journal of Language Studies, 12, 35-51.

Piirainen-Marsh, A., \& Tainio, L. (2009). Other-Repetition as Resource for Participation in the Activity of Playing a Video Game. The Modern Language Journal, 93, 153-169. http://dx.doi.org/10.1111/j.1540-4781.2009.00853.x

Poupore, G. (2014). The Influence of Content on Adult L2 Learners' Task Motivation: An Interset Theory Perspective. The Canadian Journal of Applied Linguistics, 17, 69-90.

Siti, S. C. M., \& Melor, M. Y. (2014). Attitudes and Motivation towards Learning English among FELDA School Students. Australian Journal of Basic and Applied Sciences, 8, 18.

Smith, M. S. (1994). Second Language Learning: Theoretical Foundations. New York: Pearson Education.

Souriyavongsa, T., Rany, S., Mohamad Jafre, Z. A., \& Leong, L. M. (2013). Factors Causes Students Low English Language Learning: A Case Study in the National University of Laos. International Journal of English Language Education, 1, 179-192. https://doi.org/10.5296/ijele.v1i1.3100

Stevick, E. (1976). Memory, Meaning and Method. Rowley: Newbury House.

Suh, J. S., Wasanasomsithi, P., Short, S., \& Majid, N. A. (1999). Out-of-Class Learning Experiences and Students' Perceptions of Their Impact on Conversation Skills. Victoria: Eric Clearinghouse on Language and Linguistics.

Sundqvist, P. (2009). The Impact of Spare Time Activities on Students' English Language Skills. In S. Granath, B. Bihl, \& S. Wenno (Eds.), Vagar till Sprak-Ochlitteratur (pp. 63-76). Karlstad: Karlstad University Press.

Yin, R. K. (2009). Case Study Research: Design and Methods. Thousand Oaks, CA: SAGE Publications. 
Submit or recommend next manuscript to SCIRP and we will provide best service for you:

Accepting pre-submission inquiries through Email, Facebook, LinkedIn, Twitter, etc. A wide selection of journals (inclusive of 9 subjects, more than 200 journals)

Providing 24-hour high-quality service

User-friendly online submission system

Fair and swift peer-review system

Efficient typesetting and proofreading procedure

Display of the result of downloads and visits, as well as the number of cited articles Maximum dissemination of your research work

Submit your manuscript at: http://papersubmission.scirp.org/

Or contact ce@scirp.org 